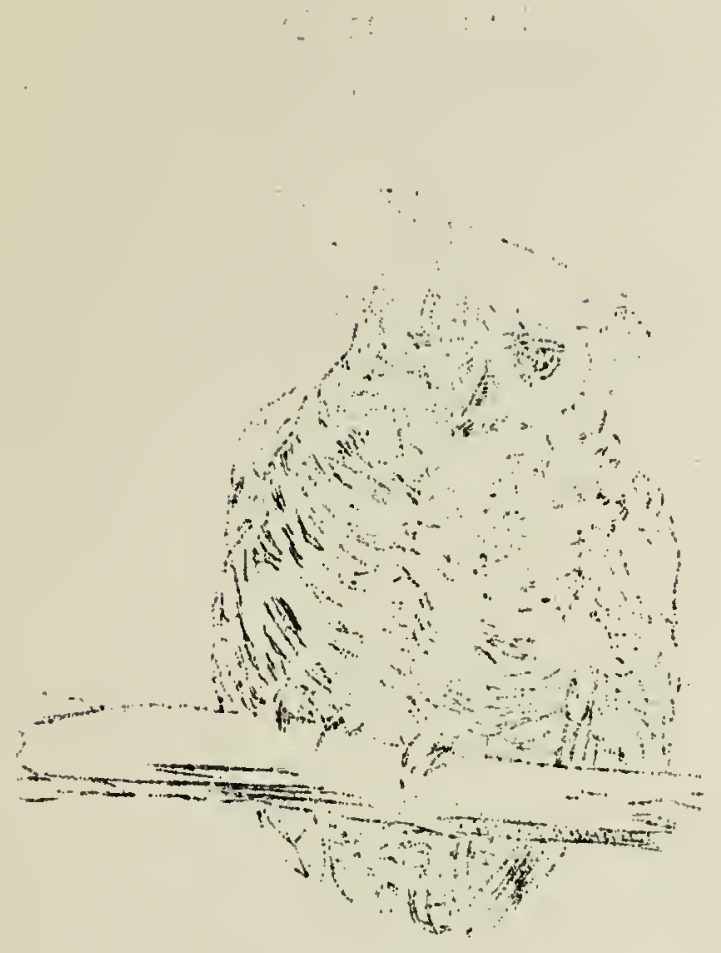

\title{
BIRD SETIONT.
}

Nr. Fred Bard, Director of the Erovincial Museum, is of the opinion that in spite of the early spring, the arrival of birds is on the arverage rery iitile earliter than other years, Soveral of our correspondents verify this idea: other: $s_{j}$ bowever, have reported that several species appeared a week or ter days earliei than usuel.

In spite of: or perhaps because of: the long dry spell it has been an ideal spring for the bird entiusiast and the letters that we hare received refleot the keen interest which has been showa. Following are exverpts from some of these:

\section{YORKTON -- CIiffe Shaw}

Ten Cedar Waxwings were seen April 11 on a clabapple tree in the C.P.R. station. These are, no doubt; the seme group of birds that have been. around during the winter. Eive Ceủr Waxwirgs were observed near the muskeg west of the city at the ine of the Christmas census. During January a fur. ther ten birds were roted on.four occasions in the down-town section and were last. seen January 13. Normally the average spring arrival date for these birds in the Yorkton district is Juke 1 , with the earliest date reoorded, as May 26, 1939 .

A lone purple martin was seen inspecting one of the bird houses at the oity hali, April 23. This was one day earlier than any pretious record here, The species arrired in full forso five days lator, April 28 . The average date has been May 4.

A Brown Úreeper was seen investigating the bark of an ejn triee on a Yorkton street, April 26, This species is only vocasionaliy seen here during migration and the date is about two days eariter than other years.

\section{TISDALE - $\mathrm{K}_{0} \mathrm{E}_{\circ}:$ Baines}

Mr. Baines has sert us sone very interesting notes on a trip he made tinis spring to Hudson Eay ard Leaf Iake. Hore are some of his bird observations: "We left IJudson Bay ai $9 \mathrm{pom}$, fpri工 2. by truck fur the Jake, a. trip of some 30 miles, two-thirds of which was throldgh uninhabited country and the final five miles on the ice of the lake. Some Mountalu Bluebirds were seen on the irip. These have nestec in telephone poles along the railm road, foun miles nortin of the "tow for sereral years now the first Canada Coose, and a lone one at that: arrivod that evening.

The next. Fay, at the far end of the lake a jewiymbuitt Bald Eagle's nest was locatea. The eagies werethere but seemed rathor shy. The nest. was in a large white poplar 300 yares from the lake shore and near the spillway on the dam where fish are always available. The nest was about 80 feet from the ground and the oilly branches on tic tree supported it. It was about six feet in diameter and the only way to get at it would be ejther to f'ell the tree or hover over it wiuh a heliocoptei.

SKULL CREEK .... SiA. ManI

"It may be of interest to some of the hambers to know that we had three tree sparrows and two robing which wintered on our ranch there were 
also two more robins at a neighbor's. A Brewer's Blackbird remained at another place about six miles distant. All the birds seemed quite perky, even on cold days. There was a great quantity of dry fruit left on the trees, which was a blessing, for those staying over as well as those which usually winter here. Bohemian Waxwings were very plentiful along the creek this winter, being in flocks of from fifty to two or three hundred. Snowbirds were very plentiful periodically. Sometimes one would see thousands and the next time at the same place there might be only very small flocks or possibly none at all. One of my neighbors said that for over a week actually acres of them were seen on a hillside.

\section{SHEHO -- William Niven}

"All through the winter there were few storms and little snowfall, but a long spell during part of January and February saw temperatures down to 30 and 40 degrees below zero. Plenty of their natural food was available for the birds owing to a good crop of wild seeds and berries last season and the light snowfall. However some of the species were entirely absent here such as the Bohemian Waxwings and Evening Grosbeaks. Most of the common winter birds were present in fair numbers all winter.

The first Horned Lark arrived Maroh 1 , which is nearly a week later than usual. A crow was seen March 3 , but this is very unusual for this district."

For purposes of comparison for others who keep winter bird records and for those who might start doing so next winter, Mr. Niven has named the following as usual winter birds at Sheho: American Coshawk, Sharp-tailed Grouse, Ruffed Grouse, European Partridge, Horned Owl, Snowy Owl, Hairy Woodpecker, Downy Woodpecker, Chickadee, Magpie, Bohemian Waxwing, Northern Shrike, Pine Grosbeak, Evening Grosbeak, Common Redpole and Snow Bunting.

of these, both species of the woodpecker as well as Chickadees visited his feeding station in the yard nearly every day.

GIROUX, Man.

\section{CHICKAD E'E FEEEDING}

Miss Frances Baird believes that there is no food more appreciated by chickadees than peanuts. For many years they have been enticed to her doorstep by these tasty morsels during the wirter months. Their preferenoe for nuts makes her wonder if worms and grubs have a nut-like flavor. I am sorry we can not answer that question.

In order to attract them she ties a bone to a tree, and then makes personal pals by feeding them nuts out of her hand.

"It was eighteen years ago," writes Miss Baird, "that the first chickadee picked my thumb-nail. Since then they have come to my hand, head, lips and even tongue to snatch a shelled nut. They disdain crumbs, currants, raisins, cocoanut and even pork rinds when it is possible to get peanuts. They are strong enough to carry a whole walnut or Brazil nut when shelled. Every spring on their departure they sing a song of gratitude."

\section{MEI.FORT -- L.T. McKim}

According to Judge McKim's bird record, which he has kept for 25 years, this year's arrival of the House Wren was the earliest. He saw the first one on Nay 9 , ten days ahead of the usual time.

"On May 15," he reports, "I saw my first Ruby-crowned Kinglet. why I had never seen it before. I have often seen the Golden-crowned. 
This is the country of the Red-tailed Hawk. Sweinson's, so comon in the south, is rarely seen in the Melfort district."

Speaking of Hawks, Mr. Cliff Shaw states that the heaviest migration of hawks he has ever noticed occurred at Yorkton, Apr11 10. Twenty-1ive Buteos were seen between 9:30 and 10:30 a.m. All: exoept five were observed during the first half hour and none were seen during the next two hours. With the exception of one Roughleg all appeared to be Red-tails. He believes these may have been scouting hawks as they came over in ones and twos. The most seen in the sky at one time was five.

\section{White-winged Crossb1118}

Miss Summers has asked us to make the following correction:

With referenoe to the four White-winged Crossbills seen by Miss Pauline Summers at Yorkton, Feb. 6, 1949 and the notation that this was bel10ved to bo the only record other than that of a female found dead two years ago by Ronald Coghill, an earlier record was listed by the late Mrs. Prlestly. In the July 1942 list of birds 1dentified in the Yorkton distriot for reoent years, Mrs. Priestly recorded a White-winged Crossbill was pioked up dead in Yorkton, April $3,1938$.

And her $\theta$ is another record:

An immature male White-winged Crossbill was found dead six miles north of Langenburg, May 8, by Darcy Wershler of Yorkton. Deroy is one of the Junior members of the Simpson Public School Naturalists' Club. He brought the speoimen to $\mathrm{Mr}$. Shaw and after having the identification verified, he and his friends performed a burial service.

HIGH HIII - - Steve Waycheshen

"Sharp-tailed Grouse are increasing here and are seon. In quite large flocks. No nests have been found up to May 7 , but it is evident they are mating.

Ruffed Grouse are seen quite commonly now and are heard druming every day. Usually they are heard druming more commonly in the evening, but lately they have been keeping it up throughout the day."

FORT SAN -- E.M. CaIIIn

\section{A Wise Mallard}

The following interesting observations have been made by $\mathrm{Mr}$. Callin. A keen observer often sees so much that most of us miss. Nature has many stories to tell; we have only to look for them. He writes:

Last year, while wandering through one of my favorite haunts by Eoho Lake at Fort San, I came upon what appeared to be a Crow's nest in a fairsized maple tree. Upon closer investigation a female Mallard flow from the nest. The nest contained a full set of eggs and of course was an old Crow's nest relined. The tree was on the bank of a oreek which contained a few feet of somewhat stagnant water (the creek bod is low enough and near enough to the Lake 
that it is always full of waiter, though there is no flow). Water had washed away some of the roots of the tree and, though the tree was still healthy, it leaned out over the water so that the nest was directly above the midale of the stream and only several feet above it. Here was one mother duck who had recognized a perfect site for a home - no ground-prowling varmints oould rob her nest and when the duoklings were ready to leave the nest they could drop safely into the water a few feet below:

I am not able to testify as to the ultimate success which this duck had last year; however, one might assume that the unorthodox venture was successful as I have the pleasure to report that the nest is again occupied by a Mallard this year. I would suppose that by long odds it is the same bird - at any rate I hope so. I had been keeping a hopeful eye on the nest during the last $f e w$ weeks and it was on May 8th that I first found the duck on the nest. She was evidently incubating too, as she sat very close on the nest even though I moved about only a few feet from her. I was tempted to take a peek in the nest but that old black devil, Mr. Crow, was watching the proceedings with more than passing interest from a tree not many yards away, and I was afraid that if I disturbed the duok the Crow would be at the nest before the mother duck got back to it.

I had heard the male Mallard as I walked along the bank of the creek and finally flushed him from the stream a hundred yards or so past the nest.

\section{THE PAS -- Rev. Rural Dean Ray Horsefield}

So interesting is the Dean's account of this rarely observed courtship, illustrating again a keenness of observation, a trait common to true naturalists only, that we have taken the liberty of clipping it from the "Chickadee Notes" of the Winnipeg Free Press. We feel sure that the editor will not mind.

"This morning I watched two (male?) Ravens pursuing a third, presumably a female: I was attracted by their crying, which had been going on for an hour, and I went out and watched them high in the air over the main mine shaft. The two pursued the one with splendid sailing acrobatics and sudden dives, while she eluded them gracefully, slipping to and fro like a flgure skater. Once in a while, the two I took to be males would haul off and peok at one another, but mostly they concentrated on showing off before the female.

One of them was eventually elected: the female swerved towards him and they came diving down from different points, then swooped together and shot up breast to breast for a moment as if kissing. They repeated this two or three times and then the female started off home towards Channing, with the male in attendance. The discarded suitor hung around for a $f$ ew moments and then I saw a fourth bird appear from nowhere alongside him. They began to sport together but presently one of them vanished but I could not tell which as they kept disappearing behind the plume of smoke of the smeiter. The remaining one went spiralling up over my head as if searching for someone, calling, calling as he went."

Dean Horsefield continues: "It was a pleasant scene to watch: I had not realized so ugly a bird could behave so gracefully under the influence of the tender passion! There have been Ravens around her summer and winter for the past three or four years, at first a single pair, now apparently more. The original pair nested at Channing: we rarely saw them in Flin Flon but this past winter I have seen Ravens in town almost every day, scavenging. Apparently they haven't read what Taverner says about their fleeing human advanoe!" 
REGINA -- Ruth and Peter MoIintock (Regina Leader)

"Bird watching," said our friend across the table, "is an anemic occupation for any man."

We didn't contradiot him, but we thought, "Brother, you've never tried it."

We have. And it is our firm conviction that people who look down their noses at other people, just because they watch birds, collect. flowers or Indian arrow heads, study the stars, or do any of the hundred-and-one things which take them out-of-doors, just don't know what the scor $\theta$ is.

You can study nature by yourself or with a group of kindred spirits. The knowiedge you pick up, no matter in what field, you will always carry with you, and it can be put to good advantage anywhere.

HAT, TDEN -- Harold KVinge

"I have observed three Western Crebes on our pond, May 3. The Iongbilled curlews seein to be more numerous this spring. I have notioed them on several occasions. I attribute the large varieties of ducks on our pond this spring to the warcity of water in the sloughs.

A pair of avocets, also a pair of burrowing owls are nesting near the pond. The McCown's Longspurs are quite numerous around here, although they are rare in many parts of Saskatchewan. Redwing Blackbirds have not been so numerous in our trees for many years. They sing almost continually. Two pelicans stayed on our pond on May 10 for several hours."

\section{YORKTON -- Miss Pauline Summers}

Miss Summers was not quite close enough to identify this sparrow on May 2, but its song was very musical - one she states that would be very difficult to forget, once having heard it. It sang, "0 ... tse-tse - tse - tsee. Doh - la - la - la - 1a." Perhaps some of our readers can identify it for her.

\section{PUNNICHY - Madeline B, Runyan}

Mrs. Runyan reports having been unable to identify a new bird very similar to a slate-colored junco, but it has bright orange-colored legs. Two of these also were seen during the summer of 1948.

\section{LEASK - GuY C. Coates}

Nr. Coates writes that on April 24 a bird alighted near where he was working. It was a little larger than a Say's Phoebe and its coloring and aotions were much like those of a Phoebe, but it had a long forked tail, quite as much out of proportion to its size as is the Magple's. He had two calls, a questioning "Chee-ip" repeated once or twice, then answered by himself with" a "Chip-pur"?

Last year a Whip-poor-will made his home near us, arriving May 25. We were somewhat disappointed in his call.

NOTE: Museum authorities and others that we talked with were unable to identify these birds from the desoriptions given. Can you?

REGINA - R.R。2 - D Doug Gilroy

We always expect at least one little nature story from Mr. Gilroy and we are not to be disappointed. Here it is:

"Apperently it is not considered bad mannered in White-crowned Sparrow circles to sing with one: s mouth full. Last Sunday, May I, I was photographing them. They would come to the little pile of seeds I put out for bait and while 
they were shelling them between their mandibles they would sing their sweet spring song - a lovely sight and sound indeed when one is only at arm's length."

On March 26 Doug found a Great Horned Owl nest in an ash tree about 25 feet from the ground. During the last half of March he noticed that magpies became very noisy and began to fly hither and thither in an excited manner. Evidently they were making wedding plans, for on March 29, to his surprise, he found the nest well on its way to completion. He believes they must have started to build March 24 or earlier.

Mr. Gilroy saw a Cooper's Hawk on April 26. It was the day after this that Mr. Fred Bard saw one at Craven. They are not oommon in this seotion of the province.

\section{KEEWATIN, Ontario -- M.A. Kittle}

We are pleased to hear from subscribers outside of Sagkatchewan and to know that they are interested in our aotivities. Mr. Kittle, writ1ng April 9 , reports that Geese are nesting in the Whiteshell district. A friend of his, Mr. Ed. Nanson, took a picture of one of their nests with three eggs in it. An old gander resented his intrusion and drove him out of the area in a hurry. Believing that there is a possibility of Whooping Cranes in his district, Mr. Kittle has requested information. We have sent him a series of bulletins on the subject.

BURNHAM - - Arthur Ward

\section{BIRD BANDING}

The only regret that Mr. and Mrs. Ward had in conneotion with their trip last summer to England was that during the period from April 28 to september 8 they temporarily had to close down bird banding operations. In spite of this, however, Mr. Ward banded 108 birds during the period that he was home. Early again this spring he has continued with the hobby and up to May 14, 77 birds, of 12 speoies have been banded. There were $1_{i}^{\text {r }}$ repeated trappings of White-crowned Sparrows. "One Robin, banded July.31, 1947, returned and was banded May 14, 1949. Following is the list:
Tree Sparrows (3)
Slate-colored Juncos (4)
White-crowned sparrows (43)
Olive-backed Thrush (2)
Lincoln Sparrows (8)
Robins (4)
White-throated Sparrows (3)
Vesper Sparrow
Song Sparrow
Clay-colored Sparrows (4)
Redwing Blackbirds (2)
Harris Sparrow

4)

\section{HYAS -- John A. Klepack}

It is encouraging to know that there is an Audubon Bird Club in Mr. Klepack's district and that the members are very keen on bird study and bird migrations. More Pine and Evening Grosbeaks and more flocks of Redpoles than usual were seen early this spring. Prairie chicken are present in large numbers and it looks -as if they are staging a real come-back.

Mr. and Mrs. Dick Bird, of Regina, are this summer making a serles of films of the wildife of the Prince Albert National Park area for the Dominion government. 


\section{PRAIRIE CHICKEN DANC ING GROUNDS}

Two more reports have come in about these, one from K.E. Baines, of Tisdale and the other from Guy $C$. Coates, Leask.

$\mathrm{Mr}$. Baines writes that there is one on the north-east oorner of the north west quarter of $T 23, R 3, W$ 2nd. This is on a quarter he farmed and is about ten miles S.W. of Saltcoats. "We also had a dancing ground of the pinnated grousefive miles west of saltcoats on either side of the road as well as right on 1t. These birds are much more showy when courting, but they are very soaroe there and I have never seen one in Tisdale."

The dancling grounds Mr. Coates refers to are on his own farm, on the north edge of $T 46, R 5, W$. of $3 r d$. In fact there are two suoh places utilized by Sharp-tailed Grouse. He has seen thirty-odd birds "daneing" at one time.

HIGH HIII -- Anton and Steve Wayoheshen

From these brothers we have recelved a most comprehensive list of 1948 Fall Migration dates, Nesting Records of 1948 and also the First Seen Dates of winter birds ior the winter of 1948-49. Inoluded in the seven-page report are some splendid observations and some unusual date records.

We are very sorry that we will not be able to report these reoords in this issue, but feel that they should be published in the fall as a most valuable guide to others who are compiling similar ones.

In the meantime the list have been turned over to the Provincial Museum and copies are being made for its reoords.

Mr. Bard wishes us to announce that such lists are of great value to the Museum and he would like to obtain as many as possible. He is hoping to distribute a serles of nature bulletins and all information of this nature is invaluable.

\section{DUCKS UNLIMITED}

Among the delegates from Western Canada to attend the oonvention of. "Duoks UnIimited" at Reno, Nevada, this spring was Judge L.T. MoKim of Molfort, one of our Directors.

In reply to a letter suggesting that he might pass on to us some items of general interest in oonnection with the convention, Judge MoKIm stated that no particularly new issue was brought up at the meetings. He was pleased to report, however, that the proposed budget of $\$ 350,000$ was approved.

"Ducks Unlimited" he writes, "is always on the lookout for new projects and would welcome suggestions. These projects should, if possible, be not too near towns. We oannot put water into a lake unless there is a source avallable but are interested in any place that can be made a good breeding ground for duoks by diverting water or building a dam." 


\section{BIRD NESTING RECORDS}

Mar. 26 Great Horned Owl (2 eggs) -- Doug Gilroy, Regina

29 Nagpie - - Doug Gilroy

Apr. 2 Mallard (5 eggs) - - S. Waycheshen, High Hill

3 Bald Eagle -- K.E, Baines, Leaf Lake

3 Nountain Bluebira -- W. Yrrohinsk1, Naicam

4 Horned Lark )

Starling, in Flicker hole) Doug Gilroy

5 Magpie (? eggs)

Mallard ( 11 eggs) ) Pauline Summers, Yorkton

5 Crows (eggs) -- Craven

Magpie (egga) -- Craven

Winte Pelican (3 nests with eggs) -- Imperial Beach)

California Gull (eggs) -- Imperial Beach -- Fred Bard, Regina

6 Killdeer -. W. Yemehinski

7 Robin ( 1 egg: ... S. Waycheshen

10 Loggerhead Shiike -. W. Yanchinski

Eastern Phoebe ( 1 egg) - In old Barn Swallow's nest -

12 Arocet )

S. Waycheshen

OrI ... H. Hvinge, Hawarden

\section{BIDD BANDING}

A. McPherson, 503 Ave F, Morth, Saskatoon, has made some interesting observations about bird banding in general and the Townsend's Solitaire and Sparrow Hawk in particuler. He writes:

"Trapping birds this spring for banding was poor; they did not seem to care for food in the uraps, so for a change I started using more water in them, and got better results.

I have found trat water for Thrushes is really good. This year I have banded more Thrushes than I have done before, and the trap I catch them in is just one for water. I had an urusual bird around my place this spring - Townsend's Solitaire. It stayed around my bird traps from April 10 to April 13. I was looking up Catalogue of the biras of Saskatchewan by H. H. Mitchell and I find one or two records of this species, one from Lake Johnston and the other at Regina on sept. 30, 1923.

During the time it stayed around my place we had a good inspection of the bird. It was not the least bit afraid of people. We got quite close to it and did not need our ficla glasses to identify its field marks. It stayed around my bird trap all day. It would perch on top of a post, sit there and watch for insects, cn seeing one it would fly down, catch the insect, then back to the same perch again. I. was keen to trap this bird for banding, but my efforts were unsuccessful. I even tried putting trout flles in my traps, suspended from the top but with no Ilick.

So far this year I have had only one Robin return which I banded last year. Last year I had six returns. We have a bigger Duck, Grebe, and Coot population in the Eudson Bay Slough this rear owing to pot holes and small sloughs being dried up.

I would like to mention about our Sparrow Hawk population. Around Saskatoon here where they usea, to be plentiful, they seem now to be about a 
bird of the past. I have recorded one this year, and I am oure it is caused by the birds being shot by people with.22 rifles, it is a great pity that this sort of thing is allowed to go on."

There are several records of the Townsend's Solitalre having been seen in Saskatchewan, although its presence so far away from the mountains is rare. C.G. Harold reports one taken May 10, 1922 at Lake Johnson. In Regina one was seen by H.H. Mitchell, Sept. 30, 1923, and one by"F. Bradshaw in 1931. Mr. C.F. Holmes reports a male taken April 2l, 1931 and a seoond bird, Sept. 10, 1933, six miles south of Dollard. Mrs. H. Flock, of Regina, saw one, April 17, 1934. Mrs. J.R. Priestly saw a single bird, just outside.Yorkton, oct. 24, 1940.

$$
\text { - Editor }
$$

\section{SPRING MIGRATION RROORDS}

We had prepared for publication a full list of "first seen" records of birds for almost every day from March 1 to May 15. S1noe this took up seven pages of closely typed material, our committee felt that it should be deleted.

The information is of considerable value and has been turned over to the Museum to be filed with similar records.

of greater interest to the majority of readers it was thought, are little atories about the antics, nesting habits, etc., of particular individuals.

For all the letters and information we have received for these records, our sinoere thanks goes to: Mrs. John Hubbard, Grenfell; H. Kringe, Hawarden; Wm. Niven, Sheho; Jack Taylor, Regina; S. Waychesen, High Hill; R.A. Nevard, Fort San; C. Shaw, Yorkton; A. Ward, Burnham; E.M. Collin, Fort San; Mrs. E.B. Flook, Regina; Pauline Summers, Yorkton;. W. Yanchinski, Naicam; Mrs. Carl Runyan, Punnichy; K.E. Baines, Tisdale; $\mathrm{Fa}$ vey Beck, Cumberland House; D. Iightbody, York Lake; Doug Gilroy; Regina; F.G. Bard, Regina; F.W. Lahrman, Regina; and A. Swanston, Regina.

\section{---And then there were 32}

It is most unfortunate that another Whooping Crase has been wantonly destroyed. Early in May the body of one was found in the Wilkie district, and It is thought that it was shot last fall while migrating to wintering grounds in rexás.

As our readers know, this species is the rarest of North American birds. Thousands of dollars have been spent in an effort to save it from extinction. Careful counts have been made of the number left. Iast winter there were only 33.

E.I. Paynter, provincial game comissioner is gravely concerned over the incldent. "It was evidonce," he said, "of the lack of consideration some individuals have for our wild life resources." He makes a plea for the oooperation of public-minded oitizens in preventing occurrences suoh as this. 